\title{
Risk Assessment of Shanghai Extreme Flooding Under the Land Use Change Scenario
}

\author{
Xinmeng Shan \\ East China Normal University \\ Jie Yin \\ East China Normal University \\ Jun Wang ( $\sim$ jwang@geo.ecnu.edu.cn ) \\ East China Normal University
}

\section{Research Article}

Keywords: land use simulation, risk assessment, adaptive strategy, Shanghai

Posted Date: June 3rd, 2021

DOI: https://doi.org/10.21203/rs.3.rs-552775/v1

License: @ (1) This work is licensed under a Creative Commons Attribution 4.0 International License. Read Full License

Version of Record: A version of this preprint was published at Natural Hazards on August 16th, 2021. See the published version at https://doi.org/10.1007/s11069-021-04978-1. 


\section{Abstract}

Environmental changes have led to non-stationary flood risks in coastal cities. How to quantitatively characterize the future change trend and effectively adapt is a frontier scientific problem that needs to be solved urgently. To this end, this study uses the 2010 Shanghai land use data as the base and uses the GeoSOS-FLUS model to simulate future land use change scenarios (2030, 2050, and 2100). Based on the results of storm and flood numerical simulations, probabilistic risk, and other multidisciplinary methods, extreme storm and flood risks of various land uses (residential land, commercial and public service land, industrial land, transportation land, agricultural land, and other land) in Shanghai are analyzed and 4 adaptation strategies to deal with extreme flooding have been developed. The research results show that: 1) Under the two emission scenarios, residential, commercial and public service, and industrial land have the highest exposure assets. Under the RCP8.5 scenario, the exposure of assets in 2100, 2050, and 2030 will be 1.7 times, 1.5 times, and 1.3 times that in 2010 for $1 / 1000$-year, respectively; the losses will be 2.7 times, 2.0 times, and 1.8 times that in 2010, respectively. 2) The spatial pattern of loss, which forms the scattered distribution of 1/10-year, is mainly distributed on both sides of the Huangpu River. For 1/1000-year, which is mainly gradually showed a strip distribution, continuous distribution of the city center, and the Qingpu-Songjiang depression in the southwest are high-risk areas for storm floods.

3) The risks are mainly distributed in the city center, the lower reaches of the Huangpu River, the northern shore of Hangzhou Bay, the Qingpu-Songjiang depression in the southwest, and Chongming Island (southwest and northeast). Our work can provide decisionmaking basis for risk-sensitive based urban planning, flood risk adaptation, and resilience building in Shanghai. The methodology can also provide a reference for risk assessment in other coastal areas.

\section{Introduction}

Many coastal cities around the world face huge risks of extreme storm floods (Najafi et al. 2021; Wolff et al. 2020; Oppenheimer et al. 2019; Shen et al. 2019; Chan et al. 2018; Nicholls et al. 2014). Under the combined influence of environmental change factors such as climate change, sea level rise, land subsidence, and rapid urbanization, the frequency and losses of future storm floods in coastal cities may increase significantly, posing severe challenges to the sustainable development of coastal cities (Catalao et al. 2020; Sadler et al. 2020; Abadie et al. 2020). There is an urgent need to understand the spatio-temporal dynamics and future trends of flood risk under environmental change scenarios to ensure the sustainable development of coastal cities (Shan et al. 2021; Du et al. 2020; Jongman et al. 2018; Hinkel et al. 2018).

At present, some scholars have carried out research on the dynamic changes of flood risk in coastal cities under the background of sea level rise, land subsidence, and climate change. For example, several researches have focused on the impact of coastal flooding on people and assets under the scenario of sea level rise for New York (Garner et al. 2017; Lin and Shullman 2017; Lin et al. 2016; Reed et al. 2015; Horton et al. 2015; Aerts et al. 2013), London (Hall et al. 2019; Hinkel et al. 2018), Ho Chi Minh City (Ngo et al. 2020; Bangalore et al. 2019; Scussolini et al. 2017), and Jakarta (Ward et al. 2011). Due to rising sea levels, the 1/500-year storm flood in New York City before the Industrial Revolution has currently become a 1/25-year storm (Garner et al. 2017; Reed et al. 2015). Hinkel et al. (2018) discussed the risks of coastal cities under the sea level rise scenario in the 21st century. Among them, Ho Chi Minh City and New York City will face considerable risks. Scussolini et al. (2017) adopted scenarios of sea level rise and socio-economic changes using two risk indicators, asset damage and potential casualties, and assessed the current and future (2050 and 2100) flood risks in Ho Chi Minh City, Vietnam. Other studies usually regard urban land or agricultural land as relatively homogeneous elements at risk, and evenly allocate GDP and assets to pixels of urban land or agricultural land (Winsemius et al. 2016; Jongman et al. 2015).

In recent years, significant progress has been made in the analysis of coastal flood loss and risk in Shanghai (Shi et al. 2020; Du et al. 2020; Shan et al. 2019; Li et al. 2019; Ke, 2014). The low-probability and high-impact compound storm flood risk has always been the focus of researchers (Wu et al. 2019; Shan et al. 2019; Li et al. 2019; Ke, 2014; Hallegatte et al. 2013; Aerts et al. 2014; Wang et al. 2012), because such risks may cause damage and huge losses to infrastructure such as buildings, assets, industries, and transportation, seriously threatening urban safety (Shan et al. 2021; Du et al. 2020; Li et al. 2019; Ke, 2014; Aerts et al. 2014; Hallegatte et al. 2013). These studies reflect the emergence of urban flood disaster risk dynamic changes, which analyzes changes in hazard factors under scenarios such as climate change, sea level rise, and land subsidence, and characterizes the state of the elements at risk with past and current land use to carry out scenarios of possible losses analysis (Du et al. 2020; Yin et al. 2015; Aerts et al. 2014). However, Shanghai's elements at risk are highly dense and complex, and the future storm and flood risk evolution 
of elements at risk is not systematically understood. Urban spatial model is an effective tool for understanding the process of urbanization and future scenarios, supporting urban planning and management policies, and evaluating the impact of the urbanization process on the environment and ecosystem (Liu et al. 2017; Filatova et al. 2016). In the field of flood disaster research, urban spatial models such as GeoSOS-FLUS model have been applied to future scenario analysis of elements at risk (Kim and Newma 2020; Liang et al. 2018; Song et al. 2017), so as to better reveal the dynamics of flood risk. Wu (2020) took Chongming's land use as the research object, considered its different future development directions, designed 3 kinds of land use change scenarios, and selected a series of driving factors, then used GeoSOS-FLUS software to predict Chongming distribution of land use in 2035. Wu (2020) takes Chongming's land use as the research object, considers its different future development directions, designs 3 kinds of land use change scenarios, and selects a series of driving factors, and uses GeoSOS-FLUS software to predict Chongming distribution of land use in 2035. Adnan et al. (2020) showed a positive correlation between flood risk and land use changes. It is estimated that the loss of coastal areas in Bangladesh caused by floods in 2030 will increase from US\$ 0.903 billion in 2005 to US\$2.096 billion. Therefore, it is necessary to predict future land use changes based on urban spatial model methods, so as to construct future elements at risk spatio-temporal change scenarios, which not only effectively assess the future risks of storms and floods, but also have important significance for improving the understanding of the dynamic evolution of risks.

Therefore, this study is based on the land use distribution data of the base year (2010), combined with the GeoSOS-FLUS model to predict the future $(2030,2050,2100)$ land use distribution pattern, and is combined with the future extreme storm and flood scenarios in Shanghai to carry out different types of land use losses and risk analysis. Our work can provide meaningful information for risk-sensitive urban planning, flood risk adaptation, and resilience building in Shanghai. The methodology can also be used for risk analysis in other coastal cities facing the threat of storm flooding.

\section{Data And Methods}

\subsection{Study Area}

Shanghai, located on the eastern edge of the Taihu dish-shaped depression in the Yangtze River Delta, is the world's largest port city with an area of $6,340 \mathrm{~km}^{2}$ and a permanent population of 24.28 million in 2019. In terms of topography, the east of Shanghai is slightly higher than the west, with an average altitude of about $4 \mathrm{~m}$. It is surrounded by water on three sides, and the Huangpu River and Suzhou River pass through the city (Fig. 1). Shanghai is affected by land subsidence due to loose Quaternary strata and human activities. According to statistics, Shanghai's maximum accumulated subsidence reached $2.99 \mathrm{~m}$, and the average land subsidence was $1.37 \mathrm{~m}$ from 1921 to 2017 . The land subsidence was controlled by measures such as restrictions on groundwater extraction and artificial recharge, gradually reducing the subsidence rate, Shanghai's average land subsidence was $5.2 \mathrm{~mm}$ in 2017 . Storm flooding caused by typhoons is the main natural disaster in Shanghai. An extreme storm flood in 1905 caused nearly 30,000 deaths. Although the construction of flood control measures in the past 50 years has effectively reduced the risk of storm floods, Typhoon Winnie in 1997, the 2005 Typhoon Matsa, the 2013 Typhoon Fitow, and the 2019 Typhoon Lekima show substantial threat of typhoon storm floods to Shanghai. Particularly, during Typhoon "Fitow", the sea winds were fierce and the Hangzhou-JiaxingHuzhou area experienced torrential rains and extreme rainstorms. The amount of flood discharge was large. For the first time since 1949, Shanghai suffered the "four encounters" disaster of wind, storm, tide, and flood (Liu et al. 2015). In the context of climate change, relative sea level rise, and urban expansion, Shanghai will face greater risks and challenges from typhoon storm floods in the future (Wang et al. 2018).

\subsection{Data}

The data used in this work mainly include Shanghai extreme storm flood scenarios in 2010, 2030, 2050, and 2100, land use data in 2010, and land price data in 2010.

\subsubsection{Extreme Storm Flood}

First, according to the height and structure of the river embankments along the Shanghai coast, the overwhelming and breaching discharges (more than $20 \mathrm{l} / \mathrm{m} / \mathrm{s}$ ) of storm surges in 1/10,100, and 1000-year are calculated. Secondly, estimation results of absolute sea level rise in the typical RCP scenario of the Yangtze River Estuary and the InSAR inversion is used to predict the settlement of coastal seawalls, it is estimated that the dikes will be flooded and broken in the 1/10, 100, and 1000-year storm surge 
scenarios in 2010, 2030, 2050, and 2100. We use a simplified 2D flood inundation model (FloodMaplnertial) to simulate dike failureinduced flooding and to derive inundation maps, and the spatial resolution is $50 \mathrm{~m}$ by $50 \mathrm{~m}$. The model assumes that the coastal/river floodplain is protected by a continuous, broad-crested embankment through which water flow exchange occurs between the sea/channel and hinterland. A simplified solution has been adopted in the model for the treatment of overland flood routing in a raster based environment. The results show that, in terms of overtopping/overflowing, this floodwall can withstand a 100-year RP event under the current condition (2010), with only two potential failure locations on the left bank of the Huangpu River's middle reach. For the 1/1000-year RP event, wave overtopping and overflowing spread to the upstream reach and the right bank of the Huangpu River (Fig. 2 and Fig. S1), with additional failures scattered throughout the middle reach. In terms of breaching due to structural failure, the floodwall along the Huangpu River is expected to remain intact under the 100year RP event until 2050, while dike breaching could occur at two locations in the upstream reach of the Huangpu River during the 1,000-year RP event with the baseline sea level (2010). Breaching further spreads to other sections of the upstream reach in the year 2030 and sparsely affects the downstream reach (Fig. 2 and Fig. S1). Chongming Island (southwest and northeast), the Qingsong low-lying area in the west, and the north bank of Hangzhou Bay are the current and future dikes with the lowest safety and the highest inundation risk area (Yin et al. 2020). With the effects of sea level rise and land subsidence, still water levels would increase proportionately at all return periods. Under the RCP 8.5 scenario, the current 10 and 100-year flood levels in Shanghai could be exceeded approximately two times more frequently in $2030,3-5$ times more frequently by 2050 , and over 50 times more frequently with a $136-\mathrm{cm}$ rise in relative sea level (50th percentile) by the end of the 21 st century. The flood inundation scenarios (degree and depth) caused by flooding increase significantly as the return period increases. Finally, the simulation results are verified. Based on a set of typhoon random events were affecting Shanghai under current climate conditions. The ADCIRC storm surge model is used to simulate the 1/10, 100, and 1000-year storm surge level distributions, and the three most severely impacted Shanghai areas of the 5,180 typhoon storm surge events were extracted. One typhoon landed on Chongming Island head-on, and one landed on Jinshan (due to the asymmetric structure of the typhoon field, the strong wind field on the right caused the Yangtze River estuary to have a higher water level than Hangzhou Bay). All results show that Chongming Island faces the greatest risk of storm surge and flooding.

\subsubsection{Future Land Use}

The land use type data of Shanghai in 2010 comes from the Shanghai Institute of Surveying and Mapping. The land use type data describes the land use type hierarchically, divided into 3 departments (one-digit code identifier), and then subdivided into 15 subsectors (2 Digit code identification), and 73 land use sub-categories (3 digit code identification) that are further divided into 6 categories, which are residential land (including urban residential land and rural homestead), commercial and public service land (including commercial service land, public management and service land), industrial land, transportation land (including railway, highway, port, airport, square, and other transportation facilities), agricultural land (including farmland, garden land, woodland) and other land (including water area, park green space, grassland, land under construction, land for other facilities, unused land, etc.). Shanghai's land use data in 2030, 2050, and 2100 are based on the 2010 land use data and are simulated using the GeoSOS-FLUS model. GeoSOS-FLUS software is a software developed on the Visual Studio 2010 platform based on the C++ language and a series of $\mathrm{C}++$ open-source libraries. It is used to simulate the changes of multiple types land use in the future under the influence of nature and human activities and nature (Liu et al. 2017). The accuracy of the simulation and results similar to the actual land use distribution can be obtained (Liu et al. 2017). It has been credibly verified that the 2030 land use forecast map is relatively uniform with the Shanghai Municipal Land Use Planning Map in 2035 in the "Shanghai City Master Plan (2017-2035)". The prediction results for the spatial distribution of land use in 2030, 2050, and 2100 show the overall spatial distribution trend of land use in the next three phases: agricultural land will gradually be transformed into commercial and public service land and residential land. Commercial and public service land in the city center are relatively dense, and public buildings and residential areas in the suburbs have gradually developed (Fig. 3).

\subsubsection{Land Use Price}

Land classification and benchmark land price for Shanghai in 2010 is determined based on different uses. The benchmark land price reflects the regional average price within the same level at the benchmark time. The land price data takes into account the influence of time factors, age, floor area ratio, regional factors, individual factors, floors, and other conditions. Among them, the benchmark land price factor correction coefficient considers regional factors (prosperity, traffic conditions, infrastructure conditions, environmental conditions, population conditions, and urban planning), individual factors (frontage conditions, parcel shape, parcel 
area), etc. In the end, residential land was $10,706 \mathrm{CNY} / \mathrm{m}^{2}$, commercial and public service land was $13,365 \mathrm{CNY} / \mathrm{m}^{2}$, industrial and mining storage land was $3604 \mathrm{CNY} / \mathrm{m}^{2}$, transportation land was $1927.2 \mathrm{CNY} / \mathrm{m}^{2}$, agricultural land was $5 \mathrm{CNY} / \mathrm{m}^{2}$, and other land was $840 \mathrm{CNY} / \mathrm{m}^{2}$. Since land prices and housing prices are closely related (Du et al. 2011), the estimation of future (2030 and 2050 year) land prices is based on the future average annual growth rate of housing prices in first-tier cities (Chen 2014), land prices in 2100 will should remain the same as in 2050.

\subsection{Methods}

This research integrates elements at risk modeling, hydrology and hydrodynamic models, and risk analysis to develop a comprehensive research framework and apply it to the future flood risk analysis of Shanghai under the land use change scenario (Fig. 4). First, the two-dimensional hydrodynamic model Floodmap is used to simulate the range and depth of storm flood inundation, and the extreme storm flood inundation maps with different return periods in 2010, 2030, 2050 and 2100 are drawn. Thirdly, the value of Shanghai's land use assets in 2010, 2030, 2050, and 2100 is analyzed with the extreme storm and flood scenarios to obtain exposed assets. Then, the land use vulnerability curve and exposed assets is combined to determine economic losses. Finally, the loss of multiple return periods is integrated, and the expected annual damage (EAD) is quantitatively analyzed.

\subsubsection{Asset Value Assessment}

Using 2010 as the base year, the asset value can be obtained by evaluating information such as the area and land value of land use in 2030,2050 , and 2100 . The calculation formula for the valuation of land use assets is:

$$
B_{\text {asset }(2030,2050 / 2100)}=\sum_{i=2010}^{2030,2050,2100}(S \times P)
$$

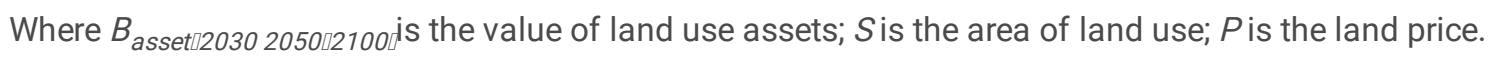

\subsubsection{Exposure Analysis}

An overlay analysis of extreme storm flooding scenarios and various land use value distribution maps in multiple return periods is used to assess land use exposure assets. The calculation formula is:

$$
E_{(2030,2050,2100)}=B_{\text {asset }(2030,2050,2100)} \cap H_{(2030,2050,2100)}
$$

Where $E_{(2030,2050,2100)}$ is the exposed asset; $B_{\text {asset }(20302050,2100)}$ is the asset value; $H_{(2030,2050,2100)}$ is hazard.

\subsubsection{Loss Analysis}

This study uses the relationship between the depth of water accumulation and the loss rate of different land types in Shanghai established by Yin et al. (2012), and finally obtains 6 types of Shanghai residential land, public construction land, industrial and mining storage land, transportation land, agricultural land, and other land use. The economic loss vulnerability curve of land use type (Fig. S2). The vulnerability curve represents the loss rate of each land use under different water depths. The calculation formula for direct economic loss of land use is:

$$
T_{\text {boss }(2030,2050,2100)}=\sum_{i=1}^{n}\left(E_{(2030,2050,2100)} \times R\right)
$$

Where $T_{\text {loss(2030, 2050, 2100) }}$ is the loss; $E_{(2030,2050,2100)}$ is the exposed assets (as shown in formula (2)); $R$ is the loss rate for different submerged depth.

\subsubsection{Risk Expression}

The estimation of risk adopts the most commonly used method in the world, that is, to express the risk in terms of expected annual damage (EAD) (Du et al. 2020; Lin et al. 2017). The calculation formula is: 
Where $E A D$ is the expected annual loss; $x$ is the flood loss (or risk value); $f(x)$ is the probability of flood loss. $E A D$ in the study area can be used as the basic basis for flood disaster cost-benefit analysis.

\section{Results}

\subsection{Exposure Assets Analysis of Land Use}

The asset value of 6 types of land use and its spatial distribution in Shanghai can be estimated based on the area and land prices using Equations (1). The spatial distributions of exposed assets for land use are mapped by overlay analysis to combine the extreme flooding inundation scenarios with the land use asset value maps in Shanghai (Fig. 5).

Our analysis shows that the exposure increases rapidly as the return periods of storm flooding increases under the two emission scenarios (Table 1), and residential, public buildings, and industrial and mining storage land have the highest exposed assets. Under the RCP8.5 scenario, the exposure of assets in 2100, 2050, and 2030 will be 1.7 times, 1.5 times, and 1.3 times that in 2010, respectively; the losses will be 2.7 times, 2.0 times, and 1.8 times that in 2010 (Table 1).

Table 1

Statistics of land use exposed to extreme storm flooding in Shanghai under RCP 8.5 scenarios (unit: million CNY)

\begin{tabular}{|c|c|c|c|c|c|c|c|c|c|c|c|c|}
\hline \multicolumn{13}{|l|}{ 峸(欧) } \\
\hline & \multicolumn{3}{|c|}{2010 year } & \multicolumn{3}{|c|}{2030 year } & \multicolumn{3}{|c|}{2050 year } & \multicolumn{3}{|c|}{2100 year } \\
\hline & 10 & 100 & 1000 & 10 & 100 & 1000 & 10 & 100 & 1000 & 10 & 100 & 1000 \\
\hline $\begin{array}{l}\text { Residential } \\
\text { land }\end{array}$ & 1075 & 1434 & 2867 & 1107 & 2215 & 3322 & 2215 & 2953 & 3942 & 3691 & 4430 & 5168 \\
\hline Industrial land & 1282 & 2564 & 3419 & 1321 & 2641 & 4842 & 2643 & 3962 & 5295 & 3962 & 5722 & 6162 \\
\hline $\begin{array}{l}\text { Commercial } \\
\text { and public } \\
\text { service land }\end{array}$ & 1181 & 1772 & 4725 & 1825 & 3042 & 6083 & 3650 & 5475 & 6867 & 5475 & 6692 & 7300 \\
\hline $\begin{array}{l}\text { Transportation } \\
\text { land }\end{array}$ & 695 & 1159 & 1854 & 1433 & 2388 & 2626 & 1910 & 2865 & 3234 & 2005 & 2865 & 3343 \\
\hline $\begin{array}{l}\text { Agricultural } \\
\text { land }\end{array}$ & 4 & 9 & 10 & 6 & 13 & 14 & 9 & 14 & 15 & 14 & 15 & 18 \\
\hline Other land & 630 & 1470 & 1680 & 865 & 1947 & 2379 & 1730 & 2379 & 2726 & 2056 & 2596 & 3028 \\
\hline Total & 4867 & 8408 & 14555 & 6557 & 12246 & 19266 & 12157 & 17648 & 22079 & 17203 & 22320 & 25019 \\
\hline
\end{tabular}

\subsection{Loss Analysis of Land Use}

By combining the exposure assets and vulnerability curves of land use, formula (3) can be used to obtain the direct economic losses caused by extreme storms and floods in different return periods of 2010, 2030, 2050, and 2100 (Table 2) and their spatial distribution (Fig. 6 and Fig. S3). Under the RCP8.5 scenario, the spatial pattern of land use loss during the return period of the three extreme storms and floods is scattered in the 1/10-year, mainly on both sides of the Huangpu River. As the return period increases, the scope and amount of losses continue to increase. When the return period is $1 / 1000$-year, the spatial pattern of loss distribution in 2030 and 2050 is mainly distributed along the banks of the Huangpu River, the main urban area will form a contiguous distribution area in 2100. At the same time, the loss of the city center concentrated on the Suzhou River mouth is gradually increasing (Fig. 6), and is mainly distributed in the city center, the lower reaches of the Huangpu River, the northern shore of Hangzhou Bay, the Songjiang area in the southwest, and Chongming Island (southwest and northeast). In the RCP2.6 scenario, the spatial pattern of loss distribution is similar to RCP8.5 scenario (Fig. S2). Under the RCP8.5 scenario, for 1/1000-year, the losses in 2100, 2050, and 2030 will be 2.7 times, 2.0 times, and 1.8 times that of 2010, respectively (Table 2). Similar to exposed assets, the loss of residential, public buildings, and industrial land accounted for the largest proportion of total losses, accounting for $80.0 \%$. 
Table 2

Statistics of land use loss to extreme storm flooding in Shanghai under RCP 8.5 scenarios (unit: million CNY)

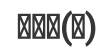

\begin{tabular}{|lllllllllllll|}
\hline & \multicolumn{3}{l}{ 2010 year } & \multicolumn{3}{c}{2030 year } & \multicolumn{3}{c|}{2050 year } & \multicolumn{2}{c|}{2100 year } \\
& 10 & 100 & 1000 & 10 & 100 & 1000 & 10 & 100 & 1000 & 10 & 100 & 1000 \\
\hline Residential land & 179 & 299 & 1076 & 185 & 647 & 1385 & 770 & 1170 & 1385 & 1693 & 2371 & 2802 \\
\hline Industrial land & 46 & 321 & 731 & 48 & 330 & 1892 & 330 & 881 & 1956 & 743 & 2477 & 2543 \\
\hline $\begin{array}{l}\text { Commercial and public } \\
\text { service land }\end{array}$ & 103 & 206 & 1238 & 319 & 638 & 1948 & 956 & 1771 & 2452 & 1069 & 2550 & 2657 \\
\hline Transportation land & 23 & 90 & 258 & 126 & 481 & 623 & 265 & 765 & 893 & 602 & 714 & 960 \\
\hline Agricultural land & 1 & 7 & 9 & 4 & 14 & 17 & 7 & 17 & 20 & 17 & 20 & 23 \\
\hline Other land & 37 & 193 & 255 & 65 & 338 & 462 & 263 & 522 & 545 & 496 & 619 & 748 \\
\hline Total & 389 & 1116 & 3567 & 747 & 2448 & 6327 & 2591 & 5126 & 7251 & 4620 & 8751 & 9733 \\
\hline
\end{tabular}

\subsection{Risk Expression}

The loss values of the 4 types of storm flood return periods are used to establish the extreme storm flood transcendence probabilityloss curve of land use (Fig. S4), and formula (4) is used to obtain EAD. Under the current scenario, Shanghai's land use EAD is 92.4 million CNY. Under the RCP2.6 scenario, Shanghai's land use EAD in 2030, 2050, and 2100 are 114.6 million CNY, 136.1 million CNY, and 337.3 million CNY, respectively (Table S1). Under the RCP8.5 scenario, the EAD of Shanghai's land use in 2030, 2050, and 2100 is 1.7 to 3.2 times that of the EAD under the RCP2.6 scenario, respectively. Residential, commercial and public service, and industrial land have the highest EAD, in 2100 they will be 209.0 million CNY, 220.5 million CNY, and 176.2 million CNY, respectively (Table 3). The risks are mainly distributed in the city center, the lower reaches of the Huangpu River, the northern shore of Hangzhou Bay, the Songjiang area in the southwest, and Chongming Island (southwest and northeast).

Table 3

Expected annual damage of land use under the RCP8.5 scenario (unit: million CNY)

\begin{tabular}{|llllllll|}
\hline & \multicolumn{2}{l}{ year } & & & & & \\
& \multicolumn{2}{l}{$\mathbf{2 0 1 0}$} & $\mathbf{2 0 3 0}$ & & $\mathbf{2 1 0 0}$ \\
\hline & & $\begin{array}{l}\text { Land price } \\
\text { unchanged }\end{array}$ & $\begin{array}{l}\text { Land } \\
\text { price rise }\end{array}$ & $\begin{array}{l}\text { Land price } \\
\text { unchanged }\end{array}$ & $\begin{array}{l}\text { Land } \\
\text { price rise }\end{array}$ & $\begin{array}{l}\text { Land price } \\
\text { unchanged }\end{array}$ & $\begin{array}{l}\text { Land } \\
\text { price rise }\end{array}$ \\
\hline Residential land & 28.8 & 46.4 & 48.0 & 97.2 & 100.2 & 202.9 & 209.0 \\
\hline Industrial land & 22.0 & 28.0 & 28.9 & 67.0 & 68.8 & 171.1 & 176.2 \\
\hline $\begin{array}{l}\text { Commercial and public } \\
\text { service land }\end{array}$ & 21.7 & 55.0 & 56.6 & 140.2 & 144.2 & 214.1 & 220.5 \\
\hline Transportation land & 6.9 & 32.0 & 32.9 & 53.1 & 54.7 & 75.4 & 77.6 \\
\hline Agricultural land & 0.5 & 1.0 & 1.0 & 1.2 & 1.3 & 1.8 & 1.9 \\
\hline Other land & 12.6 & 21.9 & 22.5 & 39.5 & 40.7 & 56.5 & 58.2 \\
\hline Total & 92.4 & 184.3 & 189.9 & 398.2 & 409.8 & 721.8 & 743.5 \\
\hline
\end{tabular}

\section{Discussion}

Shanghai is a financial center in China. It has the highest standard of flood control system in China (designed using 1/1000-year standards). However, sea level rise and land subsidence have brought major challenges to Shanghai's flood risk management, which has also caused Shanghai to be considered by foreign research as one of the coastal cities with the highest flood risk and the fastest growth rate in the world. According to estimates by Hallegatte et al (2013), among the 136 largest coastal cities in the world, 
Shanghai is one of the cities with the fastest increase in annual expected loss (EAD) (ranking 13th) compared with 2005. Wang et al (2012) have shown that sea level rise, land subsidence, storm surges, and surface runoff work together to cause more complex, variable, and sudden flood disasters. By 2100 , half of Shanghai's city will be affected by coastal floods, and $46 \%$ of seawalls and flood walls will be overwhelmed. This type of extreme floods caused by simultaneous typhoons, storm surges, astronomical tides, heavy rains, and river floods is a low probability and high impact catastrophe (Aerts et al. 2013). For example, the 2013 Typhoon "Fitow" was the first time since 1949 that Shanghai suffered the "four encounters" disaster of strong winds, storms, tides, and floods; 121,000 people were affected and the direct economic loss was 370 million CNY. Taking into account the superimposed effects of sea level rise, land subsidence, and climate change, the risk of compound extreme storm and floods to Shanghai in the future may be further increased. This kind of low-probability and high-impact extreme compound event is the focus of Shanghai's flood risk adaptation and risk decision-making.

Drawing on the flood control experience of other coastal cities abroad, Shanghai can also implement hard adaptation measures: adaptation measures based on engineering measures such as tidal sluices, flood walls, and sea dikes, which reduce flood risk by changing the probability of flood hazards, and implement soft adaptation measures: adaptation strategies based on nonengineering measures such as building codes and coastal wetlands, which mainly reduce flood risk by reducing exposure and vulnerability. From the results of this study, as the return period of storm floods increases, the city center, the Songjiang district in the upper reaches of the Huangpu River, the north bank of Hangzhou Bay, and the Qingpu-Songjiang depression in the southwest are high-risk areas for disasters and assets exposure. Different measures need to be taken to deal with storm flooding for different regions. 1) Shanghai's city center has dense population and assets. It is necessary to implement rainwater storage and peak reduction facilities such as sponge cities to strengthen the construction of flood control capabilities to enhance the safety of the city center. 2) Shanghai should focus on strengthening the flood control system in the weak sections of the upper and middle reaches of the Huangpu River and newly added urbanized areas, especially in low-lying areas such as the upstream Songjiang, the northern shore of Hangzhou Bay, and the Qingpu-Songjiang area in the southwest. Several flood diversion and discharge areas are recommended. Try not to plan and arrange hospitals, schools, residential areas, and other important units and facilities within 3 kilometers on both sides of the river. In other areas, the flood control wall should be increased according to the latest analysis of Huangpu River tide level to maintain its designed flood control capacity. On one hand, the current defensive capacity of the embankments on some of Shanghai's shores is low, and the defense standards need to be improved, such as the sea embankments on the nearby shores of Chongming North Coast, Chongming Nanmen Port, Baozhen Port, Xijia Port, Wusongkou Port, and Luchao Port. On the other hand, full attention should be paid to the impact of sea level rise and ground subsidence on the defensive capacity of embankments. Land subsidence will significantly change the shape of the underlying surface will lead to, combined with the superimposed effect of seal level rise on the water level, the reduction of the flood control project fortification standards and the weakening of flood control capacity. Therefore, regular monitoring and settlement analysis of the flood control project should be strengthened. Secondly, the construction of large-scale high-rise buildings and large-scale underground projects within $2 \mathrm{~km}$ on both banks of the Huangpu River should be strictly restricted to control the land subsidence in Shanghai, especially the land subsidence on both sides of the Huangpu River. Finally, it is possible to make full use of the ecological functions of urban green space, plan park green space, use landscape belts in flood-prone areas on both banks of the Pujiang River as flood buffer zones, and plan temporary flood diversion areas in key sections (Yin et al. 2013). 3) The Qingpu-Songjiang depression on the upper reaches of the Huangpu River should give full play to the water storage and drainage role of the river network, increase the water area of the river and lake, interrupt small river channel, dredge the sediment, control the water level of the river, and prevent the low-lying area from being flooded; 4) Due to coastal erosion at the north of Hangzhou Bay, the beach protection measures should be strengthened, especially in frontier parts of seawalls in Luchao Port and Jinshan Petrochemical Factory, and increasing dam capacity along the beach may be necessary. In addition, it is necessary to improve the local flood control infrastructure including sluices, pumping stations, embankments, and urban drainage systems to ensure the orderly construction and efficient operation of various water conservancy infrastructures are managed precisely and intelligently, and adapting various wet/dry-floodproofing measures to improve the spatial response capacity of risks, and enhance urban resilience.

\section{Conclusion}

This study presents an integrated modelling framework to analyze the exposure, loss, and risk patterns of Shanghai's various land uses (residential, commercial and public service land, industrial, transportation, agricultural, and other land use) in the future (2030, 
2050, and 2100) under extreme storm and flood, and proposes adaptation strategies to reduce flood risk. The main conclusions are as follows:

(1) Under the two emission scenarios, the exposed assets of residential, commercial and public service land, and industrial land are the highest in $2010,2030,2050$, and 2100, for 1/1000-years, they were 2.6 times, 1.5 times, and 1.8 times that of 2010, respectively. It is 2.6 times, 1.5 times, and 1.8 times that of 2010 when a 1/1000-year event occurs. The exposed assets of residential, public buildings, and industrial and mining storage land accounted for $74 \%$ of the total exposed assets in 2100 .

(2) Under the two emission scenarios, the spatial pattern of land use loss during the return period of the extreme storm flooding, which forms the scattered distribution of 1/10-year, is mainly distributed on both sides of the Huangpu River. As the return period increases, the scope and amount of losses continue to increase. For 1/1000-year, which is mainly gradually showed a strip distribution in 2030 and 2050, and formed continuous distribution of the city center and the Qingpu-Songjiang depression in the southwest in 2100. In terms of economic loss, the value of land use loss in Shanghai for 1/1000-year in 2100 is 1.7 times that of the 1/10-year under the RCP8.5 scenario. Residential, public buildings and industrial land losses accounted for the largest proportion of total losses, accounting for $26-29 \%$.

(3) Risks are mainly distributed in the city center, the lower reaches of the Huangpu River, the northern shore of Hangzhou Bay, the Qingpu-Songjiang depression in the southwest, and Chongming Island (southwest and northeast). Under the current scenario, the EAD for land use in Shanghai is 0.924 million CNY. Under the RCP8.5 scenario, the EAD of Shanghai's land use in 2030, 2050, and 2100 is 1.899 million CNY, 4.098 million CNY, and 7.435 million CNY, respectively, which is 1.7 to 3.2 times the EAD under the RCP2.6 scenario. Among them, residential, public building, and industrial land have the highest EAD.

(4) Adaptation strategies to deal with the risk of extreme storms and floods in Shanghai include: The city center needs to implement rainwater storage and peak reduction facilities such as sponge cities; Focus on strengthening the flood control system in the weak sections of the upper and middle reaches of the Huangpu River and newly-increased urbanized areas; The Qingpu-Songjiang depression in the upper reaches of the Huangpu River needs to give full play to the storage and drainage role of the river network; Coastal erosion in the northern of Hangzhou Bay should strengthen beach protection measures, especially in frontier parts of seawalls in Luchao Port and Jinshan Petrochemical Factory, and increasing dam capacity along the beach may be necessary. In addition, local flood control infrastructure including sluices, pumping stations, embankments, and urban drainage systems need to be improved.

\section{Declarations}

Acknowledgements: This research was funded by the Shanghai Science and Technology Support Program (Grant No. 19DZ1201505), the National Natural Science Foundation of China (Grant No. 41971199), and the Major Program of National Social Science Foundation of China (Grant No. 18ZDA105). The authors would like to thank Prof. Jianping Wu, for providing Shanghai's land use data in 2010. The authors would like to thank Dr. Meng Luo, for her assistance in future land use change analysis. The authors would like to thank Dr. Yuhan Yang, for her assistance in extreme storm flooding simulation.

Conflict of interest The authors declare that they have no conflict of interest.

\section{References}

1. Abadie LM, Jackson LP, de Murieta ES, Jevrejeva S, Galarraga I (2020) Comparing urban coastal flood risk in 136 cities under two alternative sea-level projections: RCP 8.5 and an expert opinion-based high-end scenario. Ocean Coastal Manage 193:105249. https://doi.org/10.1016/j.ocecoaman.2020.105249

2. Aerts JCJH, Lin N, Botzen WJW, Emanuel K, de Moel H (2013) Low-probability flood risk modeling for New York City. Risk Anal 33(5):772-788. https://doi.org/10.1111/risa.12008

3. Aerts JCJH, Botzen WJW, Emanuel K, Lin N, de Moel H, Michel-Kerjan EO (2014) Evaluating flood resilience strategies for coastal megacities. Science 344:472-474. https://doi.org/ 10.1126/science.1248222

4. Adnan M, Abdullah A, Dewan A, Hall JW (2020) The effects of changing land use and flood hazard on poverty in coastal Bangladesh. Land Use Pol 99:104868. https://doi.org/ 10.1016/j.landusepol.2020.104868

Page 9/17 
5. Bangalore M, Smith A, Veldkamp T (2019) Exposure to floods, climate change, and poverty in Vietnam. Eco Dis Cli Cha 3:79-99. https://doi.org/10.1007/s41885-018-0035-4

6. Catalao J, Raju D, Nico G (2020) InSAR maps of land subsidence and sea level scenarios to quantify the flood inundation risk in coastal cities: The case of Singapore. Remote Sens 12(2):296. https://doi.org/10.3390/rs12020296

7. Chan FKS, Chuah, CJ, Ziegler AD, Dabrowski M, Varis, O (2018) Towards resilient flood risk management for Asian coastal cities: Lessons learned from Hong Kong and Singapore. J Clean Prod 187(1):576-589.

https://doi.org/10.1016/j.jclepro.2018.03.217

8. Chen L (2014) Chinese investors should buy a house in the U.S. What kind of increase is expected (in Chinese). Tsinghua financial review 3:104-106.

9. Du SQ, Scussolini P, Ward PJ, Zhang M, Wen JH, Wang LY, Koks E, Diaz-loaiza A, Gao J, Ke Q, Aerts JCJH (2020) Hard or soft flood adaptation? Advantages of a hybrid strategy for Shanghai. Glob Environ Chang 61:102037. https://doi.org/10.1016/j.gloenvcha.2020.102037

10. Du HY, Ma YK, An YB (2011) The impact of land policy on the relation between housing and land prices: Evidence from China. The Quarterly Review of Economics and Finance 51(1):19-27. https://doi.org/10.1016/j.qref.2010.09.004

11. Filatova T, Polhill JG. van Ewijk S (2016) Regime shifts in coupled socio-environmental systems: Review of modelling challenges and approaches. Environ Modell Softw 75: 333-347. https://doi.org/10.1016/j.envsoft.2015.04.003

12. Garner AJ, Mann ME, Emanuel KA, Kopp RE, Lin N, Alley RB, Horton BP, DeConto RM, Donnelly JP, Pollard D (2017) Impact of climate change on New York City's coastal flood hazard: Increasing flood heights from the preindustrial to 2300 CE. PNAS 114(45):11861-11866. https://doi.org/10.1073/pnas.1703568114

13. Hallegatte S, Green C, Nicholls RJ, Corfee-Morlot J (2013) Future flood losses in major coastal cities. Nat Clim Chang 3(9): 802806. https://doi.org/10.1038/NCLIMATE1979

14. Hinkel J, Aerts JCJH, Brown S (2018) The ability of societies to adapt to twenty-first-century sea-level rise. Nat Clim Change 8:570-578. https://doi.org/10.1038/s41558-018-0176-z

15. Horton R, Little C, Gornitz V, Bader D, Oppenheimer M (2015) New York City Panel on Climate Change 2015 report chapter 2: Sea level rise and coastal storms. Ann NY Acad Sci 1336(1):36-44. https://doi.org/10.1111/nyas.12593

16. Hall JW, Harvey H, Manning LJ (2019) Adaptation thresholds and pathways for tidal flood risk management in London. Clim Risk Manag 24: 42-58. https://doi.org/10.1016/j.crm.2019.04.001

17. Jongman, B (2018) Effective adaptation to rising flood risk. Nat Commun 9(1):1986. https://doi.org/ 10.1038/s41467-01804396-1

18. Jongman B, Winsemius HC, Aerts JCJH, de Perez, EC, van Aalst, MK, Kron, W, Ward, PJ (2015) Declining vulnerability to river floods and the global benefits of adaptation. PNAS 112 (18):E2271-E2280. https://doi.org/10.1073/pnas.1414439112

19. Ke Q (2014) Flood risk analysis for metropolitan areas: A case study for Shanghai. Ph.D. Thesis, Delft University of Technolog, Delft, The Netherlands.

20. Kim Y, Newman G (2020) Advancing Scenario Planning through Integrating Urban Growth Prediction with Future Flood Risk Models. Comput Environ Urban Syst 82:101498. https://doi.org/ 10.1016/j.compenvurbsys.2020.101498

21. Lin N, Shullman E (2017) Dealing with hurricane surge flooding in a changing environment: part I. Risk assessment considering storm climatology change, sea level rise, and coastal development. Stoch Environ Res Risk Assess 31:2379-2400. https://doi.org/10.1007/s00477-016-1377-5

22. Lin N, Kopp RE, Horton BP, Donnelly JP (2016) Hurricane Sandy's flood frequency increasing from year 1800 to 2100 . PNAS 113(43):12071. https://doi.org/10.1073/pnas.1604386113

23. Li WJ, Wen JH, Xu B, Li XD, Du SQ (2019) Integrated assessment of economic losses in manufacturing industry in Shanghai metropolitan area under an extreme storm flood scenario. Sustainability 11, 126. https://doi.org/10.3390/su11010126

24. Liu X, Liang X, Li X, Xu XC, Ou JP, Chen YM, Li SY, Wang SJ, Pei FS (2017) A future land use simulation model (FLUS) for simulating multiple land use scenarios by coupling human and natural effects. Landsc Urban Plan 168:94-116. https://doi.org/10.1016/j.landurbplan.2017.09.019

25. Liu XC, Lu YJ, Cui D (2015) Evaluation of flood prevention abilities of seawall and countermeasures in Shanghai (in Chinese). China Flood \& Drought Management 25(06):48-52. 
26. Liang X, Liu XP, Li X, Chen YM, Tian H, Yao, Y (2018) Delineating multi-scenario urban growth boundaries with a CA-based FLUS model and morphological method. Landsc Urban Plan 177, 47-63. https://doi.org/10.1016/j.landurbplan.2018.04.016

27. Najafi MR, Zhang Y, Martyn N (2021) A flood risk assessment framework for interdependent infrastructure systems in coastal environments. Sust Cities Soc 2021, 64:102516. https://doi.org/10.1016/j.scs.2020.102516

28. Nicholls RJ, Hanson SE, Lowe JA, Warrick RA, Lu XF, Long AJ (2014) Sea-level scenarios for evaluating coastal impacts. WIREs: Climate Change 5(1):129-150. https://doi.org/ 10.1002/wcc.253

29. Ngo LM, Kieu L T, Hoang HY, Nguyen, HB (2020) Experiences of housing adapted to sea level rise and applicability for houses in the Can Gio District, Ho Chi Minh City, Vietnam. Sustainability 12, 3743. https://doi.org/10.3390/su12093743

30. Oppenheimer M, Glavovic BC, Hinkel J, Roderik VDW, Magnan A, Abd-Elgawad A, Rongshu C, Jara Miguel C, Robert DC, Ghosh T, Hay J, Ben M, Meyssignac B, Sebesvari Z, Smit AJ, Dangendorf S, Frederikse T (2019) Sea level rise and implications for lowlying islands, coasts and communities. In: IPCC Special Report on the Ocean and Cryosphere in a Changing Climate. Publisher IPCC.

31. Reed AJ, Mann ME, Emanual KA, Lin N, Horton BP, Kemp AC, Donnelly JP (2015) Increased threat of tropical cyclones and coastal flooding to New York City during the anthropogenic era. PNAS 2015, 112:12610-12615. https://doi.org/10.1073/pnas.1513127112

32. Sadler J M, Goodall J L, Behl M, Bowes BD, Morsy MM (2020) Exploring real-time control of stormwater systems for sea level rise. J Hydrol 583:124571. https://doi.org/ 10.1016/j.jhydrol.2020.124571

33. Shen Y, Morsy MM, Huxley C, Tahvildari N, Goodall JL (2019) Flood risk assessment and increased resilience for coastal urban watersheds under the combined impact of storm tide and heavy rainfall. J Hydrol 579:124159. https://doi.org/10.1016/j.jhydrol.2019.124159

34. Scussolini P, Tran TVT, Koks E, Diaz-Loaiza A, Ho PL, Lasage R (2017) Adaptation to sea level rise: a multidisciplinary analysis for Ho Chi Minh city, Vietnam. Water Resour Res 53:10841-10857. https://doi.org/10.1002/2017WR021344

35. Shi XW, Qiu JF, Chen BR, Zhang XJ, Guo HS, Wang J, Bei ZY (2020) Storm surge risk assessment method for a coastal county in China: case study of Jinshan District, Shanghai. Stoch Environ Res Risk Assess 34(2):627-640. https://doi.org/10.1007/s00477-020-01791-3

36. Shan XM, Wen JH, Zhang M, Wang LY, Ke Q, Li WJ, Du SQ, Shi Y, Chen K, Liao BG, Li XD, Xu H (2019) Scenario-based extreme flood risk of residential buildings and household properties in Shanghai. Sustainability 11:3202. https://doi.org/10.3390/su11113202

37. Song J, Fu X, Gu Y, Deng YJ, Peng ZR (2017) An examination of land use impacts of flooding induced by sea level rise. Nat Hazards Earth Syst Sci 17 (3):315-334. https://doi.org/10.5194/nhess-17-315-2017

38. Shan XM, Du SQ, Wang LY, Li WJ, Hu HZ, Wen JH (2021) Flood risk dynamics and adaptation analyses for coastal cities based on internet big data and hydrology-hydrodynamic models (in Chinese). Chin Sci Bull 66:1-13. https://doi.org/10.1360/TB-20201536

39. Wolff C, Nikoletopoulos T, Hinkel J, Vafeidis AT (2020) Future urban development exacerbates coastal exposure in the Mediterranean. Sci Rep 10, 14420. https://doi.org/10.1038/s41598-020-70928-9

40. Ward P J, Marfai M A, Yulianto F, Hizbaron DR, Aerts JCJH (2011) Coastal inundation and damage exposure estimation: a case study for Jakarta. Nat Hazards 56(3):899-916. https://doi.org/ 10.1007/s11069-010-9599-1

41. Winsemius HC, Aerts JCJH, van Beek LPH, Bierkens MFP, Bouwman A, Jongman B, Kwadijk JCJ, Ligtvoet W, Lucas PL, van Vuuren DP, Ward PJ (2016) Global drivers of future river flood risk. Nat Clim Chang 6(4):381-385. https://doi.org/10.1038/NCLIMATE2893

42. Wu JD, Ye MQ, Wang X, Koks E (2019) Building asset value mapping in support of flood risk assessments: A case study of Shanghai, China. Sustainability 11(4):971. https://doi.org/ 10.3390/su11040971

43. Wang J, Gao W, Xu SY, Yu LZ (2012) Evaluation of the combined risk of sea level rise, land subsidence, and storm surges on the coastal areas of Shanghai, China. Clim Change, 2012, 115(3-4):537-558. https://doi.org/10.1007/s10584-012-0468-7

44. Wang J, Yi S, Li MY, Wang L, Song CC (2018) Effects of sea level rise, land subsidence, bathymetric change and typhoon tracks on storm flooding in the coastal areas of Shanghai. Sci Total Environ 621:228-234. https://doi.org/

10.1016/j.scitotenv.2017.11.224

Page $11 / 17$ 
45. Wu SD (2020) Scenario Study of Land Use Change and Hazard Risk Exposure for Future Chongming Eco-islands (in Chinese). M.S. Thesis, East China Normal University.

46. Yin J, Jonkman S, Lin N, Yu DP, Aerts J, Wilby R, Pan M, Wood E, Wood E, Bricker J, Ke Q, Zeng ZZ, Zhao Q, Ge JZ, Wang J (2020) Flood Risks in Sinking Delta Cities: Time for a Reevaluation? Earth Future 8:1-15. https://doi.org/ 10.1029/2020EF001614

47. Yin J, Ye MW, Yin ZE, Xu SY (2015) A review of advances in urban flood risk analysis over China. Stoch Environ Res Risk Assess 29(3):1063-1070. https://doi.org/10.1007/s00477-014-0939-7

48. Yin J, Yin ZE, Yu DP, Xu SY (2012) Vulnerability Analysis for Storm Induced Flood: A Case Study of Huangpu River Basin (in Chinese). Sci Geogr Sin 32(9):1155-1160.

49. Yin J, Yin ZE, Yu DP, Xu SY (2013) Hazard analysis of extreme storm flooding in the context of sea level rise: A case study of Huangpu river basin (in Chinese). Geogr Res 32(12):2215-2221.

\section{Figures}

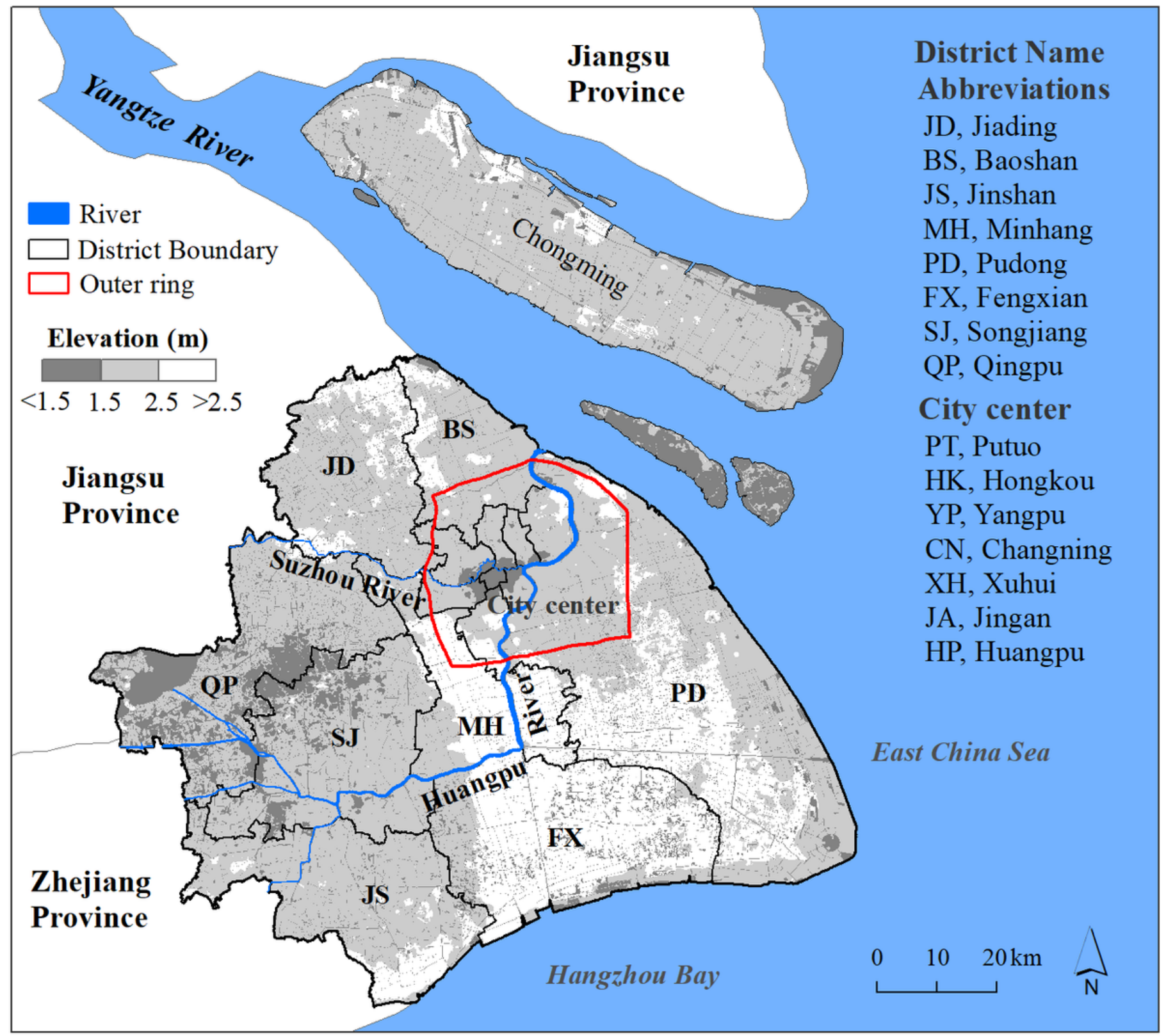

Figure 1 
Shanghai's location and elevation Note: The designations employed and the presentation of the material on this map do not imply the expression of any opinion whatsoever on the part of Research Square concerning the legal status of any country, territory, city or area or of its authorities, or concerning the delimitation of its frontiers or boundaries. This map has been provided by the authors.
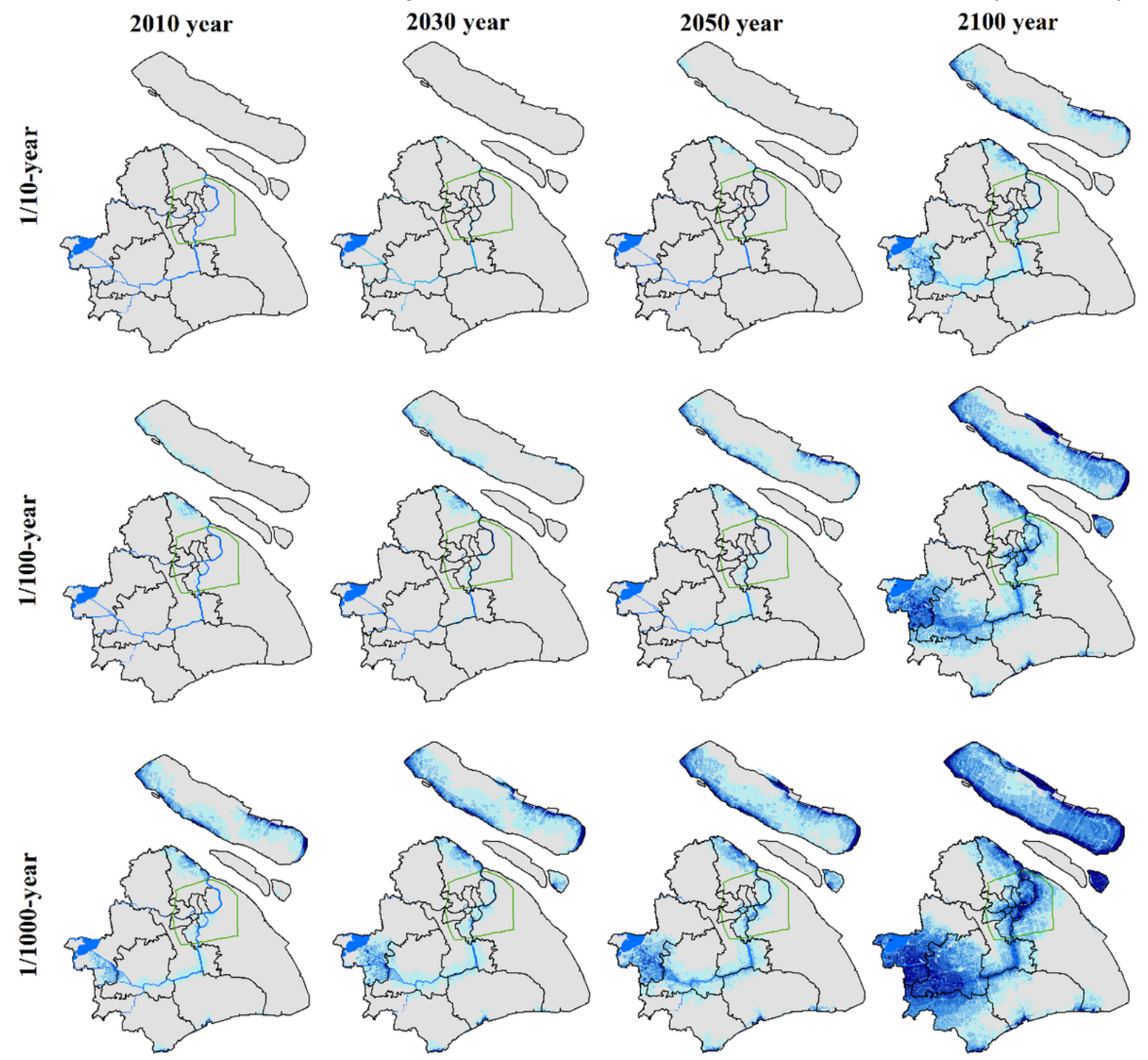

\section{Inundation Depth (m)}

\section{Out ring River}
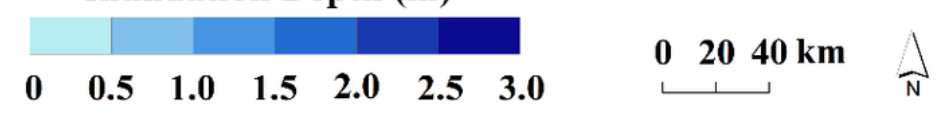

\section{Figure 2}

Inundation maps with extent and maximum depth caused by extreme flooding as a function of return periods under the RCP8.5 scenario Note: The designations employed and the presentation of the material on this map do not imply the expression of any opinion whatsoever on the part of Research Square concerning the legal status of any country, territory, city or area or of its authorities, or concerning the delimitation of its frontiers or boundaries. This map has been provided by the authors. 

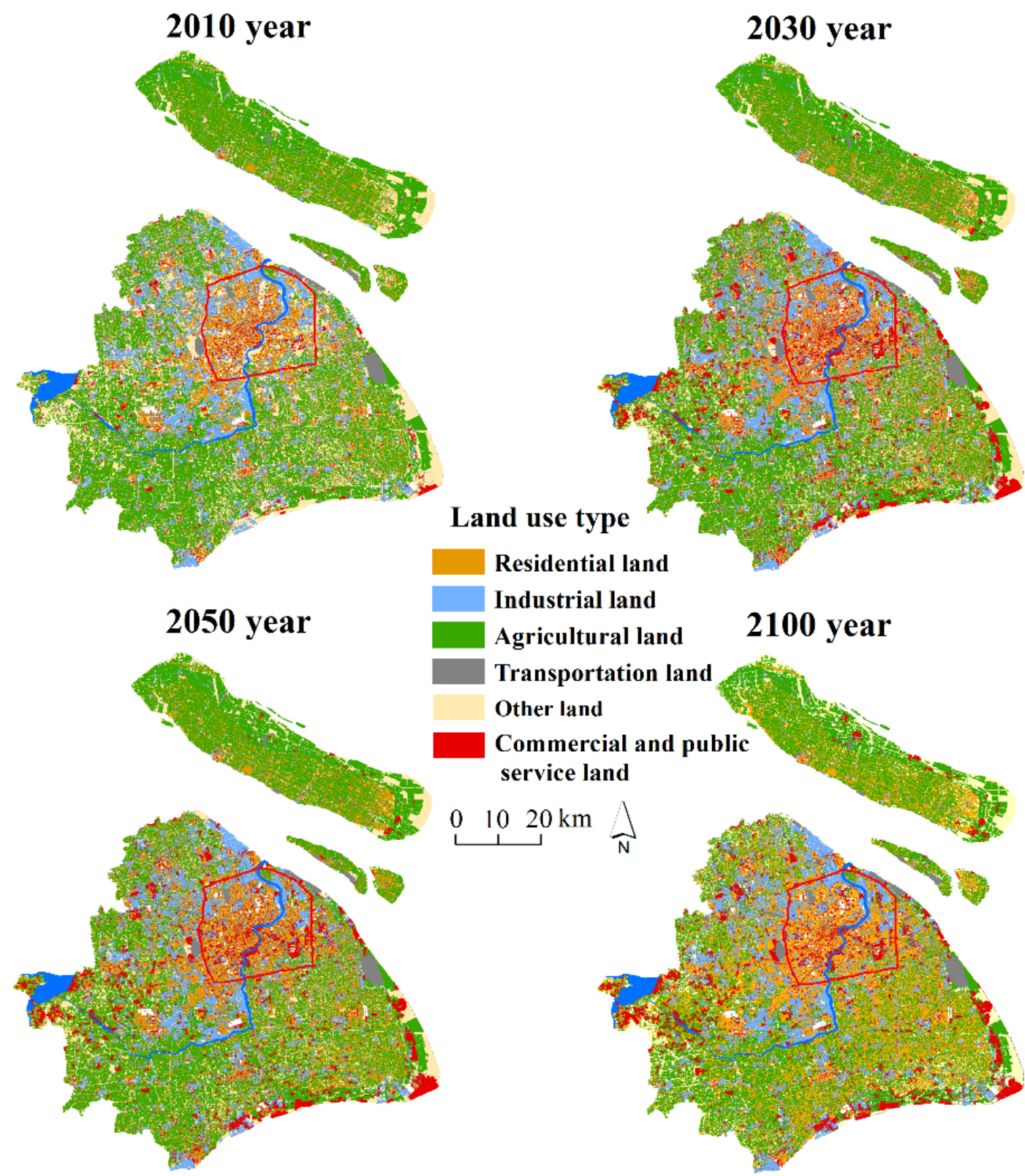

Industrial land

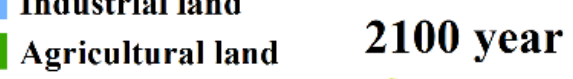

Transportation land

Other land

\section{Commercial and public} service land

$\stackrel{10}{0} \quad 10 \mathrm{~km} \bigwedge_{\mathrm{N}}$

\section{Figure 3}

Prediction for spatial distribution of Shanghai land use in 2030, 2050, and 2100 Note: The designations employed and the presentation of the material on this map do not imply the expression of any opinion whatsoever on the part of Research Square concerning the legal status of any country, territory, city or area or of its authorities, or concerning the delimitation of its frontiers or boundaries. This map has been provided by the authors. 


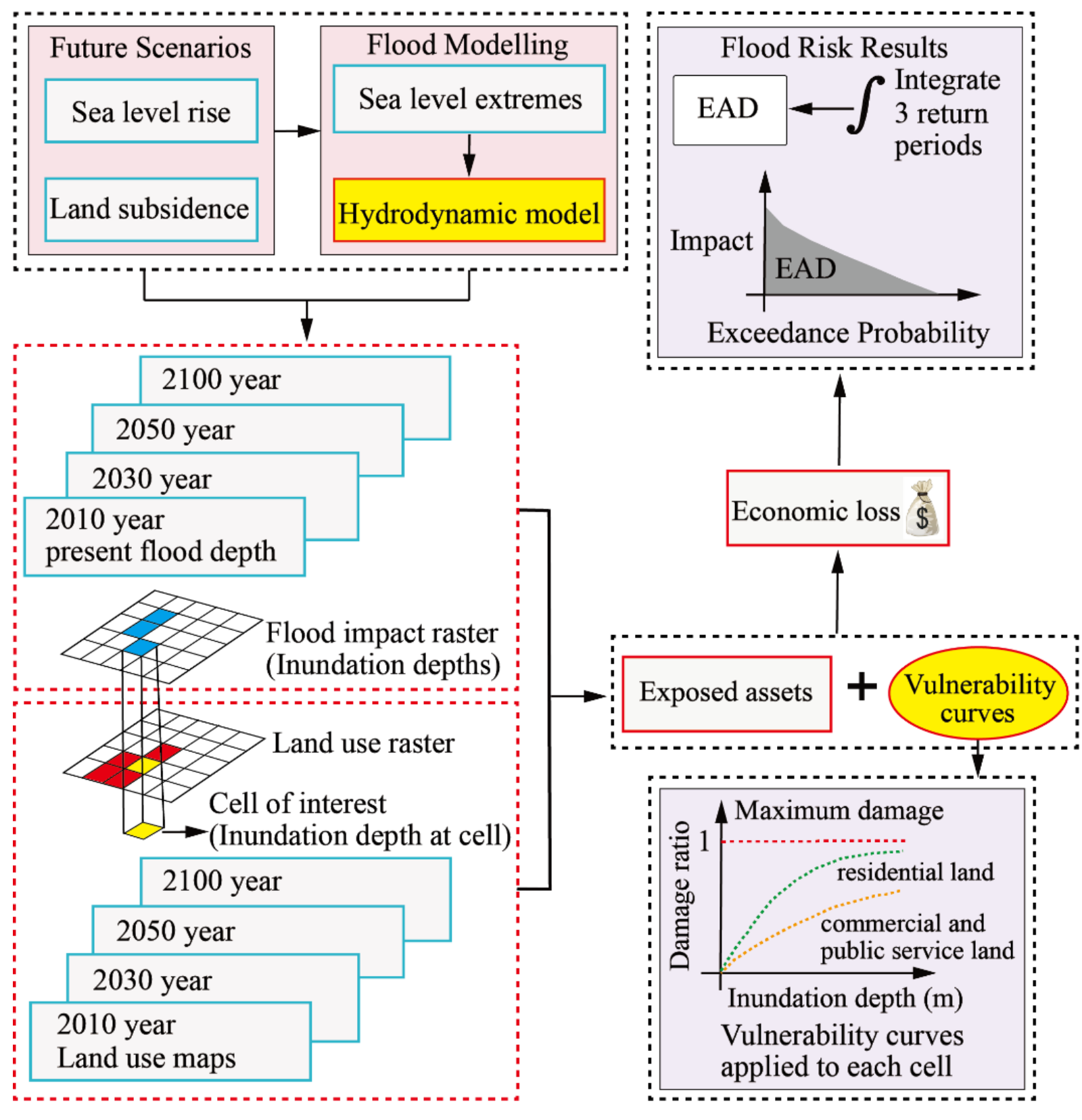

Figure 4

The methodology framework 

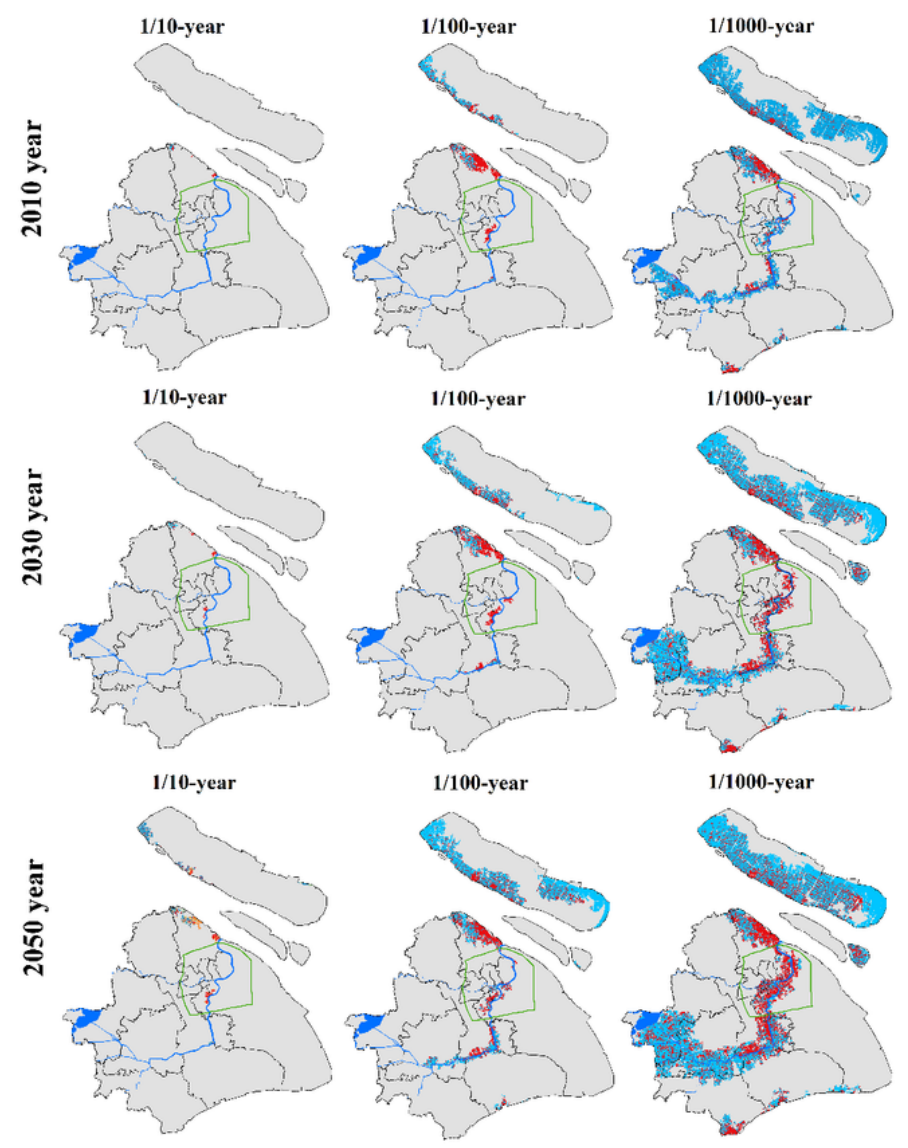

1/1000-year
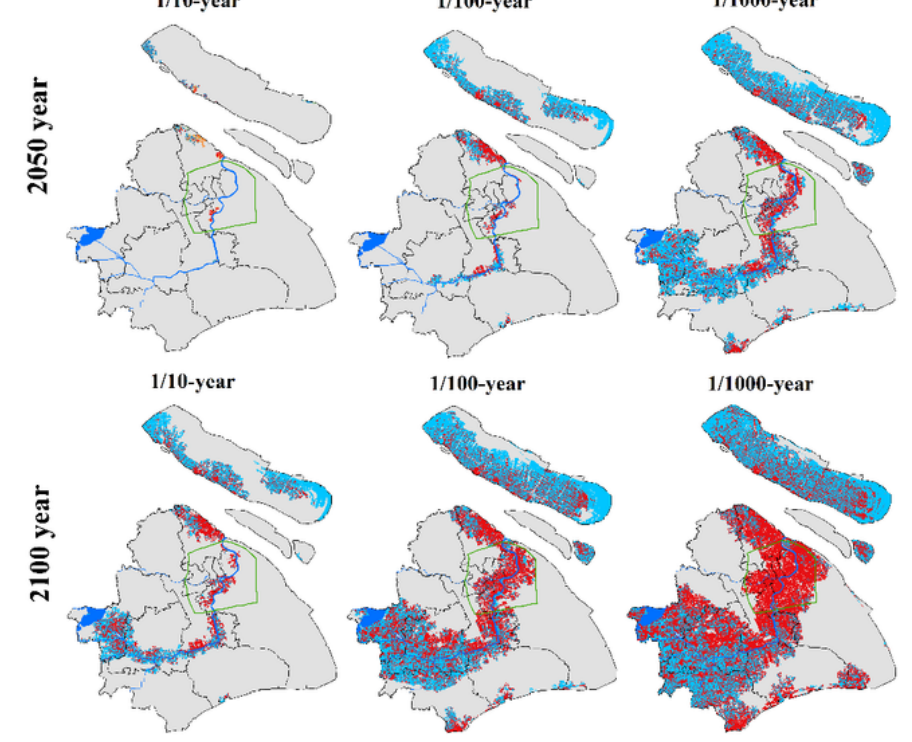

Exposed assets (million $\mathrm{CNY} / \mathrm{km}^{2}$ )

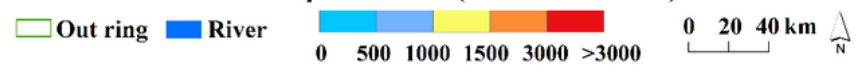

\section{Figure 5}

Distribution of exposed assets per unit area (increased land price) under the extreme flood scenarios in Shanghai under the RCP8.5 scenario Note: The designations employed and the presentation of the material on this map do not imply the expression of any opinion whatsoever on the part of Research Square concerning the legal status of any country, territory, city or area or of its authorities, or concerning the delimitation of its frontiers or boundaries. This map has been provided by the authors. 

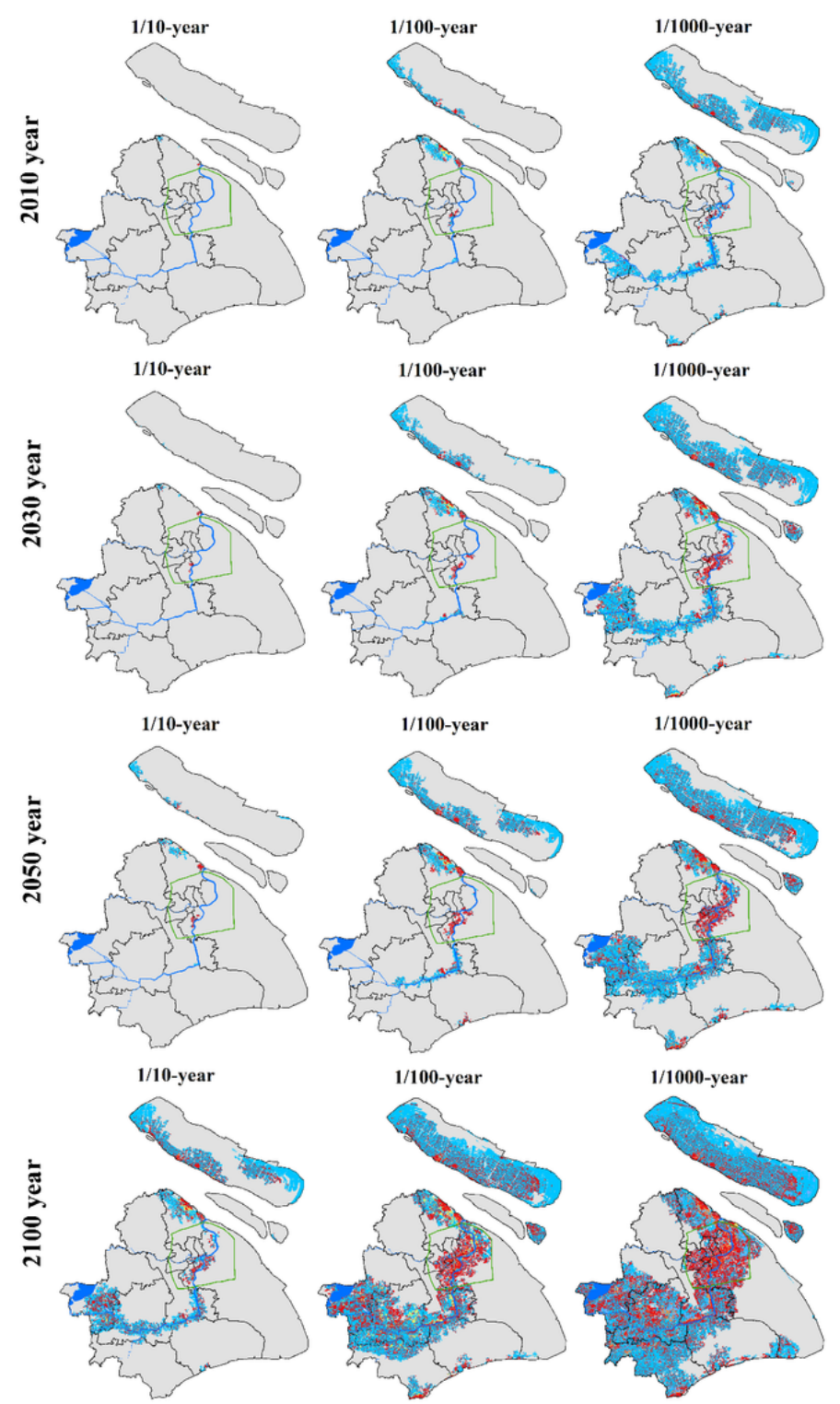

Losses (million CNY/km²)

$\square$ Out ring $\square$ River

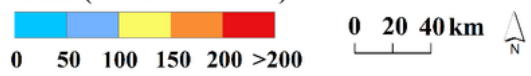

\section{Figure 6}

Distribution of loss per unit area (increased land price) under the extreme storm flood scenarios in Shanghai under the RCP8.5 scenario Note: The designations employed and the presentation of the material on this map do not imply the expression of any opinion whatsoever on the part of Research Square concerning the legal status of any country, territory, city or area or of its authorities, or concerning the delimitation of its frontiers or boundaries. This map has been provided by the authors.

\section{Supplementary Files}

This is a list of supplementary files associated with this preprint. Click to download.

- SupplementalMaterials.docx 